Recenzja: Antologia polskiej poezji w Szwecji. Głosy poetek, wprowadzenie, wybór, opracowanie Ewa Teodorowicz-Hellman, Stockholm Slavic Papers 29, Stockholms Universitet Institutionen för Slaviska och Baltiska Språk, Finska, Nederlänska och Tyska, 2020, ss. 298.

\title{
„(E)migrantki”. \\ Recepcja poezji Polek mieszkających w Szwecji
}

\author{
Paweł WOJCIECHOWSKI ${ }^{1}$ \\ Uniwersytet w Białymstoku
}

\begin{abstract}
I
W a ż n o ś ć

Przedłożona do recenzji antologia składa się z dwóch zasadniczych części: wielostronnego Słowa wstępnego i nachylonego antropologicznie studium Głosy polskich poetek $w$ Szwecji Ewy Teodorowicz-Hellman oraz wyboru wierszy polskich autorek. Książkę zamykają noty biograficzne poetek w opracowaniu Tadeusza Nowakowskiego i Ewy Teodorowicz-Hellman. „Celem książki - precyzuje badaczka w Słowie wstępnym - jest prezentacja twórczości polskich poetek mieszkających w Szwecji, ukazanie jej różnorodności w kontekście podejmowanej problematyki, wiodących motywów i form wyrazu poetyckiego. (...) Autorki, których twórczość ujęta jest $\mathrm{w}$ antologii, spełniają kilka kryteriów: nadrzędnym z nich jest fakt, iż są
\end{abstract}

\footnotetext{
1 https://orcid.org/0000-0001-8826-5318

Uniwersytet w Białymstoku, Wydział Filologiczny

p.wojciechowski@uwb.edu.pl
} 
(e)migrantkami, wyjechały $\mathrm{z}$ Polski głównie $\mathrm{w}$ latach siedemdziesiątych i osiemdziesiątych, przez długi czas mieszkały w Szwecji, gdzie powstawały ich utwory poetyckie, które zaczęły się ukazywać w zbiorkach poetyckich na początku lat dziewięćdziesiątych ubiegłego wieku" (s. 7).

W takiej optyce Antologia polskiej poezji w Szwecji. Głosy poetek jest książką ważną i ważką z kilku powodów. Po pierwsze prezentuje twórczość liryczną osiemnastu autorek - „(e)migrantek” (s. 7) - Polek, które opuściły kraj w dobie rdzennej ustrojowej opresyjności i rozmaitych europejskich fermentów społeczno-kulturowych, politycznych i historycznych. Szwecja stała się dla nich nowym miejscem na Ziemi, nowym zakresem egzystencjalnym, lepszą, „czułą” codziennością. Jednak tylko „zewnętrznie”, bytowo, materialnie, instytucjonalnie itp. „Wewnętrznie” autorki nie zmieniły siebie, swojej tożsamości, koligacji rodzinnych czy przyjacielskich, różnoimiennych przynależności. Pogłębiły się w nich jedynie warstwy palimpsestu odczuć i uczuć, tęsknot, samotności, obcości, stygmaty „bycia nie u siebie”.

Po drugie, z całą mocą należy zgodzić się z Ewą Teodorowicz-Hellman, iż w centrum uwagi nie pozostają same poetki, ale „POEZJA, jaka zrodziła się i nadal powstaje w szwedzkiej przestrzeni geograficznej, językowej i kulturowej” (s. 7). I to jest najlepsza $\mathrm{z}$ możliwych strategii edycyjnych i badawczych, bowiem w materii treściowej samej POEZJI znajduje się to, co prymarne - zapis doświadczeń egzystencjalnych: jednostkowych, pokoleniowych i kulturowych.

Po trzecie, w tym wielowątkowym zapisie pełnym uniwersalizmu, humanizmu, wymiarów: filozoficznego, socjologicznego, kulturowego i nadto kwalitatywnego kobiecego punktu widzenia - doskwiera zasmucająca niestety pewna kategoria braku. Braku wydawnictw współczesnych polskich autorów obecnych w zasobach bibliotek szwedzkich (s. 8). Wydawnictw tego typu traktowanych jako „swoiste efemerydy” (ib.) - edytowanych w małych nakładach i zazwyczaj własnym sumptem na szwedzkim rynku czytelniczym (tak przecież chłonnym), nie wspominając o edycyjnym „braku” polskim. W tym aspekcie Antologia polskiej poezji ${ }_{w}$ Szwecji. Głosy poetek jest nowatorskim projektem naukowym i popularyzatorskim.

\section{II}

W a ż k o ś ć

W części poprzedzającej wybór kompozycji poetyckich - zatytułowanej: Głosy polskich poetek w Szwecji - Ewa Teodorowicz-Hellman w sposób dogłębny przeprowadza egzegezę twórczości polskich autorek piszących na 
obczyźnie. Prymarna w tej egzegezie jest interpretacja twórczości lirycznej Polek z antropologicznego punktu widzenia. Już sam wybór tekstów do antologii posiada głęboki wymiar filozoficzny, antropocentryczny i osobisty, dzięki czemu stosunek czytelników do tych utworów nabiera otwartości na kontekst, symbol, metaforę, literalność. Dwie komplementarne płaszczyzny egzystencji: realna i wzniosła pozwalają lepiej zrozumieć intencje poszczególnych autorek i odnieść do ich doświadczeń własne, osobne perspektywy i kategorie egzystencjalne. Trafność doboru tekstów inicjuje proces nadawania istotnych znaczeń sferze materialnej, przedmiotowej, czasowo-przestrzennej oraz niematerialnej, obszarowi wartości wyższych (np. topoi homo viator, homo computer, topos arkadyjski, filozofia życia, duchowość, wiara, modlitwa, Bóg).

Kolejną ważkością wyłaniającą się $\mathrm{z}$ przedkładanej antologii jest osobliwie dostrzegany personalizm wydobyty $\mathrm{z}$ ponowoczesnej kondycji kobiecej. Uważnością staje się tutaj jednostkowość, dostrzeganie perspektywy płci, feminizmu, bezcennej podmiotowości, indywidualności. To, co personalistyczne, intymne, szalenie ważkie - staje się wartością samą w sobie. Wydaje się, iż wyborowi utworów do antologii przyświecała badaczce strategia Montaigne'owska: „sam jestem materią mej książki” (M. de Montaigne, Próby. Księga pierwsza, tłum. T. Żeleński-Boy, Warszawa 1985, s. 139). TeodorowiczHellman celnie odczytuje wspomnianą kondycję, co jest bazowym walorem antologii. Eksplorując lirykę swoich bohaterek, uczona odnajduje tam najczystszą prawdę egzystencji (człowiek będący w drodze, przemijanie, topika opuszczenia domu, obcości, estetyka nostalgii, opresje indywidualne i zbiorowe, wiara, przyroda, śmierć).

Intuicja, wielotorowe spojrzenie i wrażliwość oraz analityczność badaczki sprawia, że liryki poddane lekturze holistycznej układają się $\mathrm{w}$ dokument człowieka i jego życia - osobisty, złożony $\mathrm{z}$ zapisków codzienności, epizodów autobiograficznych. Dlatego antologia ma tak silną moc oddziaływania na czytelnika, bowiem dyskurs „głosów poetek” jest utkany z prawdziwych zdarzeń, uczuć i przeżyć, z autentycznych emocji. Krystalizując swój koncept i komponując antologię Ewa Teodorowicz-Hellman udowodniła, że najsilniej działa na innych prawda jednostki, osobnego życia i przeżycia - co stanowi niesłychanie ważki i znaczący trop uniwersalistyczny. Poprzez czytanie doświadczeń innych ludzi lepiej rozumiemy siebie i mechanizmy kierujące rzeczywistością. Autorka, dzięki umiejętnemu zestawieniu tych tekstów, wielokrotnie odsłania „szczeliny istnienia” (termin Jolanty BrachCzainy), elementy niedostrzegane $\mathrm{w}$ głównym strumieniu codzienności, 
miejsca (np. interesujące i zaskakujące semantycznie opisy Sztokholmu, s. 22 i n.), ludzkie sprawy i postawy - po to, by wytłumaczyć prymarne wymiary kulturowej inności (etnograficzne, autoetnograficzne, autobiograficzne) oraz kulturowy dystans. Doskonałym uzupełnieniem, domknięciem znaczeń, sensów, metafor i literalności są ilustracje (na okładce i we wnętrzu antologii) Danki Jaworskiej.

Antologia polskiej poezji w Szwecji. Głosy poetek, pod redakcją naukową Ewy Teodorowicz-Hellman stanowi bezcenną pozycję książkową i lekturę obowiązkową nie tylko w środowiskach polonijnych, ale jako literackie świadectwo, dokument egzystencji Polek mieszkających w Szwecji w drugiej połowie XX i w dwóch pierwszych dekadach XXI stulecia. 